sufficient supply of supporting technicians is available, to reduce the wastage of potential ability from. the schools or in other ways, or to foster the information services and the national library system upon which that efficiency so largely depends.

It is not right to suggest that the universities of Great Britain are indifferent to the problems of fitting students for life in the modern world. The recent suggestion of the General Board of the Faculties of the University of Cambridge for a new Tripos examination, and Sir Eric Ashby's May Lecture to the Institute of Metals on "Technological Humanism" are examples of how university circles are prepared to consider ways of meeting these problems. Much, however, that remains to be done must fall on the professional institutions and learned societies and on industry itself, particularly in regard to the efficient use of existing man-power and in indicating the extent to which the supply of particular categories should be expanded. Nevertheless, the major contribution must come from the Government side. Neither the plea for further thought about the functions of the schools, the technical colleges, the colleges of technology and the universities in the light of the deeper question: What is the end and aim of a human life ? nor the progress already made in the expansion of technical education or in cooperation between industry and the universities, should be allowed to distract attention from the shortcomings of the Government in these respects. The simple truth is that Britain's investment in her schools and technical colleges and universities is the surest safeguard of her future. It must be maintained and expanded to the limits which the inquiries adumbrated indicate, whatever the sacrifice to be made elsewhere in other social services or in the resources lavished upon recreation and amusement.

\section{THE UNIVERSITY OF CALCUTTA}

\section{Hundred Years of the University of Calcutta}

A History of the University issued in Commemoration of the Centenary Celebrations. Pp. $\mathrm{xxi}+539+258$ illustrations. (Caleutta: The University, 1957.) Rs. 25.

YNIVERSITY histories are difficult both to write and to read. Piety demands a detailed record of professors and departments, of benefactors and officers, which is mostly of only local interest. It is difficult, through that mass of material, to display, or to grasp, the main themes of the story. Calcutta's centenary volume attempts it in the form of eight chapters, written by eight members of its staff, and although there is some overlap and some discontinuity, and catalogues cannot be entirely avoided, yet themes are conspicuous and they remain distinct.

Higher education on a Western model began in India a century and a half ago, in the form of sporadic colleges, some private, some with Government support. The first University was that of Calcutta, established in 1857 as an examining body, which affiliated colleges to itself, conducted entrance and degree examinations for their students, and thereby exerted an important but external influence on their teaching. Not until half a century later did it become a teaching institution itself and then only at graduatelevel and in certain professional schools. Its 80,000 undergraduates are to-day still mostly in affiliated colleges. To adjust the relations between University and colleges has been a major and continuing problem. So also has been the relation between University and Government. The University, like some of its colleges, was a Government creation, largely Government managed. Too much Government control, in the pre-1947 years, was seen as foreign domination, but also as a limitation of academic freedom. In 1923 it was dramatically, but unsuccessfully, resisted, at a time when the University had weakened its own position through getting into financial difficulties; its famous vice-chancellor, Asutosh Mookerjee, then scornfully rejected Lord Lytton's offer to re-appoint him for a further term, because the offer was coupled with a condition that he withdraw his opposition to the Government's University Bill. 'The University is still more a subject of the Government than a partner with the Government, but a step towards responsible independence was taken in the Calcutta University Act of 1951, which recast the constitution and re-organized the administration.

Burdened on one hand by so large a brood of foster-children (there are now 123 colleges), and hampered on the other by severe financial limitation and close dependence on the Government, the University has nevertheless struggled to achieve good academic standards. In the work of its best scholars and in its development of research it has had undoubted success, but at undergraduate-level the recent flood of students has overwhelmed it. "There is hardly any doubt that the gain in quantity has been offset by the loss in quality. The mechanical examination system, defective teaching, expenses of education, decline of the middle class and many other factors are responsible for the fall cf standard." So writes the author of Chapter 8 ; and the ViceChancellor in his crisp foreword, recognizing this situation, is much more concerned. with the task of the future and the restoration of standards than with casting his eye over the past. So, among the handicaps, complacency is not one, and therefore in spite of the dismay that strikes the insular English visitor at the sheer size of the place and its problems, we may expect the University of Calcutta in its own way to find the answers, and to maintain the place of respect which it holds among the universities of the Commonwealth.

ROBERT AItKeN

\section{INFECTION BY ANAEROBES}

\section{Biologie des Maladies dues aux Anaérobies}

Par A. R. Prévot. (Collection de l'Institut Pasteur.) Pp. 572. (Paris: Éditions Médicales Flammarion, 1955.) 2,225 franes.

$T$

HIS book can be regarded as a continuation of the classic treatise of Weinberg, Nativelle and Prévot, "Les Microbes Anaérobies", which gave a comprehensive survey of the anaerobes and infections eaused by them for the period 1877-1937. The present volume carries on where the earlier one left off, and deals with the period 1937-55.

In the admirable introduction the author explains the purpose of the book. The main emphasis is on 